\title{
Prearrest Silence as Evidence of Guilt: What You Don't Say Shouldn't Be Used Against You
}

\author{
Jane Elinor Notz†
}

"You have the right to remain silent." In the landmark case of Miranda $v$ Arizona, the Supreme Court articulated the familiar list of rights that police must give any arrestee before conducting a custodial interrogation, including the "right to remain silent." But the right to silence articulated by Miranda only attaches once the defendant is in custody and has received the requisite warnings. In Jenkins $v$ Anderson, ${ }^{2}$ the Supreme Court faced a defendant who, after allegedly murdering his victim, left the scene and was not arrested until he turned himself in to the police two weeks later. Testifying on his own behalf at trial, the defendant maintained he had killed in self-defense, a story he had not previously told the police. During cross-examination and the closing statement, the prosecutor used the defendant's silence between the time of the murder and his arrest to impeach the defendant's credibility. According to the prosecution, if the defendant did act in self-defense, he would have told his exculpatory story earlier. ${ }^{3}$ In affirming the conviction, the Court held that a prosecutor's use of prearrest silence for impeachment purposes does not violate the Fifth Amendment. ${ }^{4}$

But Jenkins addressed only the use of prearrest silence for impeachment purposes. The Court explicitly left open the constitutionality of substantive use of prearrest silence. ${ }^{5}$ In a substantive use case, the prosecutor does not introduce the prearrest silence to impeach the defendant's credibility at trial. Instead, the prosecutor uses the silence to suggest guilt.

For example, in Savory $v$ Lane, ${ }^{6}$ the police first approached the defendant a week after a double murder. Although they did not arrest the defendant, they did try to interrogate him. The de-

$\dagger$ B.A. 1990, The University of Pennsylvania; J.D. Candidate 1998, The University of Chicago.

1384 US 436, 444 (1966).

2447 US 231 (1980).

${ }^{3}$ Id at 232-35.

- Id at 238.

- Id at $236 \mathrm{n} 2$ ("Our decision today does not consider whether or under what circumstances prearrest silence may be protected by the Fifth Amendment.").

${ }^{6} 832$ F2d 1011, 1014 (7th Cir 1987). 
fendant refused to answer, saying that he was unwilling to discuss the case in any way. ${ }^{7}$ The defendant did not testify at trial. Nonetheless, the prosecutor introduced the prearrest silence in his case-in-chief. Hoping to suggest guilt, the prosecutor sought to convince the jury that if the defendant were innocent, he would not have refused to give a statement to the police during the prearrest investigation. ${ }^{8}$ The Seventh Circuit excluded the silence, holding that a prosecutor's use of a defendant's prearrest silence as evidence of guilt violates the Fifth Amendment. ${ }^{9}$

The Savory rule has not been universally followed. Instead, appellate courts have disagreed about whether a prosecutor may make substantive use of a defendant's prearrest silence in his case-in-chief. ${ }^{10}$ In reaching divergent outcomes, the circuit courts rely on two distinct strands of Fifth Amendment case law. ${ }^{11}$ The

'Id at 1015 (The defendant told the police that "he didn't want to talk about it, he didn't want to make any statements.").

${ }^{8}$ Id.

${ }^{9}$ Id at 1017-18.

${ }^{10}$ The First, Seventh, and Tenth Circuits have held that admission of such evidence violates the Fifth Amendment privilege against self-incrimination. Coppola $v$ Powell, 878 F2d 1562 (1st Cir 1989) (holding that defendant's privilege against self-incrimination was violated when prosecutor used defendant's prearrest refusal to make a statement to police as evidence of defendant's guilt); Savory, 832 F2d at 1017-18 (holding that prosecutor's comment on defendant's refusal to speak with police during prearrest investigation violated defendant's Fifth Amendment privilege); United States $v$ Burson, 952 F2d 1196 (10th Cir 1991) (holding that defendant's privilege against self-incrimination was violated when prosecutor used defendant's prearrest refusal to answer IRS investigator's questions as evidence of defendant's guilt). The Fifth and Eleventh Circuits, however, have held that admission of such evidence does not violate the privilege. United States $v$ Zanabria, 74 F3d 590 (5th Cir 1996) (finding no Fifth Amendment violation in prosecutor's use of nontestifying defendant's prearrest silence); United States $v$ Rivera, 944 F2d 1563 (11th Cir 1991) (finding no constitutional violation in prosecutor's use of defendant's prearrest refusal to speak with customs inspector as evidence of defendant's guilt). Additionally, the Second Circuit has suggested, without deciding, that substantive use of a defendant's prearrest silence may be improper. United States $v$ Caro, 637 F2d 869, 876 (2d Cir 1981). The Ninth Circuit has encountered the issue but declined to address it, finding that the district court's decision to admit defendant's partial prearrest silence was not "plain error" in light of the unsettled state of the law. United States $v$ Thompson, 82 F3d 849, 854-56 (9th Cir 1996).

"A third approach, not cited by the circuit courts, would be to allow substantive use of prearrest silence on the grounds that the silence is not compelled self-incrimination, and thus is not protected by the Fifth Amendment. See Bruce J. McKeegan, Note, The Fifth Amendment and a Defendant's Prearrest Failure to Come Forward: The Sounds of Silence, 46 Albany L Rev 546, 556 (1982) (arguing that prosecutor's use of defendant's failure to come forward does not violate Fifth Amendment because "compulsion violating the privilege refers to a court's imposition of fines or imprisonment, pursuant to the enforcement devices of contempt, in an endeavor to force a recalcitrant witness in an investigative proceeding to incriminate himself'). This approach has its origins in the history of the Fifth Amendment, which viewed the privilege as a safeguard against torture and other improper methods of interrogation. See Albert W. Alschuler, A Peculiar Privilege in Historical Perspective: The Right to Remain Silent, 94 Mich L Rev 2625, 2651 (1996). However, as this Comment discusses, the modern Supreme Court has indicated that 
circuits that favor exclusion of prearrest silence rely on Griffin $v$ California. ${ }^{12}$ In Griffin, the Supreme Court suggested that the Fifth Amendment guarantees an absolute right to remain silent, and accordingly ruled that a prosecutor may not comment on a defendant's failure to take the stand. ${ }^{13}$

The circuits that favor admitting prearrest silence as evidence of guilt rely on the Court's more recent holding in Jenkins. ${ }^{14}$ In Jenkins, the Court failed to follow the view it had adopted in Griffin that the Fifth Amendment provides an absolute right to silence, holding instead that courts must employ an "impermissible burden" test to determine the constitutionality of impeachment use of prearrest silence. To apply this test, a court weighs the legitimacy of the challenged practice against the extent to which that practice impairs the policies behind the Fifth Amendment. ${ }^{15}$

This Comment argues that a prosecutor's use of prearrest silence as evidence of guilt violates the Fifth Amendment, but courts that have reached this outcome rely on what may be an outdated test. ${ }^{16}$ Part I examines the Supreme Court's decision in

lesser levels of persuasion may violate the Fifth Amendment.

${ }^{12} 380$ US 609 (1965).

${ }^{23}$ Id at 613-15 (holding that a section of the California state constitution that allowed comment on a defendant's refusal to testify violated the Fifth Amendment).

14 447 US 231.

${ }^{15}$ Id at 237-38.

${ }^{16}$ This Comment does not argue that substantive use of prearrest silence violates either the Due Process Clause of the Fourteenth Amendment or the rules of evidence. Although such arguments may be made, a detailed discussion of them is beyond the scope of this Comment.

In Doyle v Ohio, 426 US 610, 617-18 (1976), the Supreme Court relied on the Fourteenth Amendment to hold that a defendant's post-Miranda silence is not admissible for impeachment purposes because it would be "fundamentally unfair" and a violation of due process for the police to assure a defendant, via the delivery of the Miranda warnings, that her silence will not be used against her, and then allow the prosecutor to introduce the defendant's silence at trial. Under Doyle's reasoning, one may argue that it is similarly unfair to use a defendant's prearrest silence against her. Thanks to television and the movies, Miranda is probably the most widely known decision of criminal procedure. It is reasonable to believe that a defendant might remain silent in reliance on her knowledge of the warnings without actually having received the warnings. However, the Supreme Court has limited Doyle to post-Miranda silence. See, for example, Jenkins, 447 US at 240 (holding that a defendant's prearrest silence may be used to impeach his trial testimony because if defendant has not received explicit Miranda warnings, there is no unfairness in holding his silence against him). For an argument that Jenkins was wrongly decided, see Barbara Rook Snyder, A Due Process Analysis of the Impeachment Use of Silence in Criminal Trials, 29 Wm \& Mary L Rev 285, 330-340 (1988) (arguing that it is fundamentally unfair and a violation of the Fourteenth Amendment to hinge the admissibility of a defendant's pretrial silence on receipt of the Miranda warnings).

Alternatively, one might argue that it is possible to dispense with the question whether prearrest silence is admissible as evidence of guilt on evidentiary grounds alone, upon a finding that the prejudicial effect of the silence exceeds its probative value. The 
Griffin and discusses the Court's view that the Fifth Amendment provides an absolute right to silence. Part II argues that, although the Griffin approach supports a prohibition against substantive use of prearrest silence, the Supreme Court has so undermined Griffin that it is unlikely to use this case to preclude the use of prearrest silence as evidence of guilt. Part II also examines the Court's decision in Jenkins and sets forth the Court's "impermissible burden" test. Part III then explains how the Court applied the impermissible burden test in Jenkins to hold that impeachment use of prearrest silence does not violate a defendant's privilege against self-incrimination. Finally, Part IV applies the impermissible burden test anew to substantive use, and maintains that, under the Jenkins balancing test, a prosecutor's use of prearrest silence as evidence of guilt violates the Fifth Amendment.

\section{GRIFFIN AND THE RIGHT TO SILENCE}

\section{A. The Griffin Penalty Doctrine}

In Griffin, the Supreme Court held that the Fifth Amendment prohibits a prosecutor from commenting on a defendant's failure to testify at trial, and similarly prohibits a court from instructing the jury that such silence is evidence of guilt. ${ }^{17}$ Relying on what has come to be known as the "penalty doctrine,"

\footnotetext{
Supreme Court has shown a willingness to use an evidentiary analysis to resolve questions regarding the admissibility of a defendant's silence-in lieu of reaching the constitutional issues. See Grunewald v United States, 353 US 391 (1957) (holding that a prosecutor cannot use a defendant's refusal to testify before a grand jury against the defendant at trial, because the prejudicial effect of the grand jury silence exceeds its probative value); United States v Hale, 422 US 171 (1975) (In this precursor to Doyle, the Court held that a prosecutor cannot use a defendant's post-Miranda silence against him at trial because the prejudicial effect of the silence exceeds its probative value.). For a discussion of state court decisions holding that prearrest silence is not admissible because of its low probative value and high potential for undue prejudicial effect, see State $v$ Easter, 130 Wash 2d 228, 922 P2d 1285, 1288 n 5 (1996). But see Snyder, 29 Wm \& Mary L Rev at 297-301 (arguing that a defendant's prearrest silence may at times be sufficiently probative of guilt to warrant admission).

${ }^{17} 380$ US at 615. The following year, in Miranda, the Court reinforced this expansive reading of the Fifth Amendment privilege, holding that, prior to custodial interrogation, police must inform suspects of their "right to remain silent." 384 US at 444. Although Miranda dealt specifically with the inadmissibility of custodial confessions, the Court suggested in a footnote that the prosecution may not use the defendant's silence at trial. Id at $468 \mathrm{n} 37$ (" $\mathrm{T} \mathrm{t}$ is impermissible to penalize an individual for exercising his Fifth Amendment privilege when he is under police custodial interrogation. The prosecution may not, therefore, use at trial the fact that he stood mute or claimed his privilege in the face of accusation.").

${ }^{18}$ See Geoffrey R. Stone, The Miranda Doctrine in the Burger Court, $1977 \mathrm{~S}$ Ct Rev 99, 147 (referring to the Griffin rule as the "penalty doctrine").
} 
Court explained that comment by a prosecutor on a defendant's failure to take the stand violates the Fifth Amendment because it "is a penalty imposed by courts for exercising a constitutional privilege. It cuts down on the privilege by making its assertion costly." ${ }^{19}$ The Court's reasoning leads to the conclusion that the Fifth Amendment forbids any government practice that punishes a defendant for remaining silent or otherwise discourages her from asserting her privilege against self-incrimination.

Followed to its logical end, the Griffin rule should clearly bar substantive use of prearrest silence. First, the protections of the Fifth Amendment are not limited to the trial context. The Supreme Court has long held that the privilege may be asserted in any situation where the defendant might make selfincriminating statements that could be used against her in a future criminal proceeding. ${ }^{20}$ Absent this expansive understanding of the Fifth Amendment, the privilege would lose its meaning. As the Court explained in Michigan v Tucker, "an inability to protect the right at one stage of a proceeding may make its invocation useless at a later stage." ${ }^{21}$ If the Fifth Amendment applied only to statements made by the defendant at trial, the state would be able to force a defendant to incriminate herself before trial, and then introduce the prior statements at trial. In admitting the pretrial statements, a court would, in essence, compel the defendant to incriminate herself.

Second, if the prosecutor is allowed to use a defendant's early silence to suggest guilt, the defendant is improperly penalized for her decision to remain silent. In Griffin, the Court was concerned that, if the prosecutor is allowed to comment on a defendant's failure to testify at trial, the defendant will be punished for remaining silent by having her silence used against her. Facing the possibility of such a penalty, the defendant will be less likely to exercise her privilege against self-incrimination. ${ }^{22}$ Likewise, if a prosecutor can use a defendant's prearrest silence against her at trial, the defendant is penalized for remaining si-

${ }^{19}$ Griffin, 380 US at 614. See also Miranda, 384 US at 460, quoting Malloy $v$ Hogan, 378 US 1, 8 (1964) ("[T] he privilege is fulfilled only when the person is guaranteed the right 'to remain silent unless he chooses to speak in the unfettered exercise of his own will."').

${ }^{25}$ See, for example, Counselman v Hitchcock, 142 US 547, 562 (1892); McCarthy $v$ Arndstein, 266 US 34, 40 (1924); Kastigar v United States, 406 US 441, 445 (1972) (holding that the privilege "protects against any disclosures that the witness reasonably believes could be used in a criminal prosecution or could lead to other evidence that might be so used") (emphasis added).

${ }^{21} 417$ US 433, 440-41 (1974).

${ }^{2}$ Griffin, $380 \mathrm{US}$ at 614 . 
lent prior to arrest, and is induced to make a statement to the police at her first opportunity. As in Griffin, such a penalty will discourage defendants from exercising their Fifth Amendment privilege.

Third, the Griffin "penalty doctrine" must prohibit a prosecutor's use of a defendant's prearrest silence, because comment on prearrest silence is likely to penalize a defendant for remaining silent more substantially than is comment on a failure to testify. In many cases in which a prosecutor seeks to make substantive use of a defendant's prearrest silence, the defendant does not take the stand. ${ }^{23}$ If the defendant does not take the stand, absent prosecutorial comment, the jury will not know that the defendant remained silent prior to arrest and cannot draw a negative inference from the silence. In contrast, when the defendant fails to testify at trial, her silence is obvious to the jury, which can then draw its own conclusions. The judge may instruct the jurors that they are not to infer guilt from the defendant's failure to take the stand, ${ }^{24}$ but if the judge's instructions are not effective, the jury might infer guilt from the defendant's silence-regardless of the Griffin prohibition against prosecutorial comment. ${ }^{25}$

\section{B. Applying Griffin to Prearrest Silence}

Griffin does not address the use of prearrest silence. Nonetheless, an expansive interpretation of Griffin would prohibit a prosecutor's use of a defendant's decision to remain silent when-

${ }^{23}$ In each of the cases reflecting the circuit split that is the subject of this Comment, the defendant chose not to take the stand. Coppola v Powell, 878 F2d 1562 (1st Cir 1989); United States v Burson, 952 F2d 1196 (10th Cir 1991); Savory, 832 F2d 1011; United States v Rivera, 944 F2d 1563 (11th Cir 1991); United States v Zanabria, 74 F3d 590 (5th Cir 1996).

${ }^{2}$ The Griffin Court reserved the decision as to whether a defendant can require that the jury be instructed that his at-trial silence can be disregarded. 380 US at $615 \mathrm{n} 6$. In Carter $v$ Kentucky, the Court reached the reserved question and held that a court is required to provide such an instruction upon the defendant's request. 450 US 288,305 (1981).

${ }_{25}^{25}$ It is possible a court may discount the "penalty" created by admitting prearrest silence. The Griffin rule was premised on the fact that if a prosecutor can comment on a defendant's failure to take the stand, the defendant will be discouraged from remaining silent. This concern may not apply in the context of prearrest silence. If the defendant does not know (1) that a decision to remain silent prior to arrest could be used against her at trial, or (2) that she will even face trial, the possibility that a prosecutor can introduce her prearrest silence will not discourage her from remaining silent. This argument is weakened, however, by the fact that many defendants make their decision to speak or remain silent prior to arrest after consulting with a lawyer or based on personal knowledge of the law. Thus, the possibility that a defendant's prearrest silence will be used against her will impact her decision to remain silent. See Anne Bowen Poulin, Evidentiary Use of Silence and the Constitutional Privilege Against Self-Incrimination, 52 Geo Wash L Rev 191, 210 (1984). 
ever such use could penalize the defendant for exercising her constitutional right. The First, Seventh, and Tenth Circuits have adopted this interpretation. These courts, relying on Griffin, have held that the prosecution may not use a defendant's prearrest silence as evidence of guilt. In Savory, for example, the Seventh Circuit cited Griffin to reach the conclusion that this use of prearrest silence violated the defendant's Fifth Amendment privilege against self-incrimination. The court explained that Griffin "applies equally to a defendant's silence before trial, and indeed, even before arrest." ${ }^{26}$ Although these courts have achieved the correct result in disallowing substantive use of prearrest silence, their reliance on Griffin places them on shaky ground, given the Supreme Court's recent treatment of Griffin. Although the Supreme Court has never overruled Griffin, the Court has so undermined its holding that Griffin may be limited to silence at trial. ${ }^{27}$ If so, Griffin alone cannot adequately resolve the constitutionality of a prosecutor's use of prearrest silence as evidence of guilt.

$\Rightarrow$ Savory, 832 F2d at 1017. See also Coppola $v$ Powell, 878 F2d 1562, 1567-68 (1st Cir 1989) (citing Griffin and explaining that the issue presented by the admission of defendant's refusal to answer police questions prior to arrest "is essentially the same as those addressed in cases defining the boundaries for prosecutorial comment on a defendant's exercise of the fifth amendment privilege"); United States $v$ Burson, 952 F2d 1196, 1201 (10th Cir 1991) (citing Griffin to prohibit substantive use of prearrest silence).

${ }^{27}$ See Part II. The Court has also undercut Miranda by suggesting that the Miranda warnings constitute procedural safeguards and are not constitutionally mandated. Consequently, today Miranda probably guarantees a right to remain silent only while the defendant is undergoing custodial interrogation. See Michigan v Tucker, 417 US 433, 439, 444 (1974) (explaining that the Miranda warnings are "procedural safeguards [ ] not themselves protected by the Constitution," but only "prophylactic rules developed to protect" and "provide practical reinforcement for the right against compulsory selfincrimination"). In contrast, the Court has never suggested that the Griffin rule is not required by the Constitution.

What constitutes "custodial interrogation" is sometimes unclear. See, for example, Oregon v Elstad, 470 US 298, 315 (1985) (citing confusion over whether police questioning in the living room of a suspect who has not been told he is under arrest amounts to custodial interrogation). However, resolution of the custodial interrogation problem, including whether prearrest questioning could under some circumstances trigger the Miranda protections, would not answer the question of whether prosecutorial use of prearrest silence violates the Fifth Amendment. The Supreme Court has held that Miranda's right to remain silent is triggered not by the existence of custodial interrogation but by the suspect's receipt of the required warnings. Fletcher $v$ Weir, 455 US 603, 606-07 (1982) (holding that a prosecutor may use the defendant's postarrest silence to impeach his trial testimony because the silence was not induced by the receipt of the Miranda warnings). 


\section{THE RIGHT TO SILENCE IN A POST-GRIFFIN WORLD: THE JENKINS BALANCING TEST}

In recent years, the Supreme Court has taken a dim view of the penalty doctrine. ${ }^{28}$ Suggesting that the Fifth Amendment does not guarantee an absolute right to silence, the Court has held that the Constitution does not prohibit every government action that might penalize the exercise of the privilege.

Where Griffin explained that a prosecutor's comment on a defendant's failure to take the stand was improper because it might discourage the defendant from remaining silent, the $\mathrm{Su}$ preme Court has subsequently maintained that the criminal justice process properly requires defendants to make difficult choices. ${ }^{29}$ For example, in McGautha $v$ California ${ }^{30}$ the Supreme Court held that a single jury may constitutionally both decide a defendant's guilt and determine his sentence. The defendant had argued that the determination of guilt and punishment at a single trial violates the privilege against self-incrimination, because such a practice discourages the defendant from remaining silent at the culpability stage of the trial for fear that, if found guilty, the jury will sentence him without having heard from him. ${ }^{31} \mathrm{Al}-$ though the Court acknowledged that, in a single-verdict trial, the defendant may be pressured into taking the stand, the Court held that the penalty for remaining silent is not sufficiently serious to violate the Fifth Amendment. ${ }^{32}$ Similarly, in Baxter $v$ Palmigiano, ${ }^{33}$ the Court held that the Constitution permits officials at a prison disciplinary hearing to draw an adverse inference from an inmate's refusal to testify. The Court refused to extend

\footnotetext{
${ }^{25}$ See Stone, $1977 \mathrm{~S} \mathrm{Ct}$ Rev at 146-47 (cited in note 18) (explaining the Supreme Court's dim view of the penalty doctrine after Griffin).

${ }^{2}$ See McGautha $v$ California, 402 US 183, 213 (1971) (explaining that the criminal justice process often requires defendants to make difficult choices and that the Constitution does not forbid the government from requiring these choices). See also Snyder, 29 Wm \& Mary L Rev at 313 (cited in note 16) (explaining that the Supreme Court has always been careful to make a distinction between forcing a defendant to make a difficult choice, which is acceptable, and government compulsion, which is not). For a useful discussion of the Court's treatment of the penalty doctrine, see Stone, 1977 S Ct Rev at 14247 (cited in note 18).

${ }^{30} 402$ US 183 (1971).

${ }^{31}$ Id at 213.

${ }^{32}$ Id at 216-17. The Court also explained that "it is not thought inconsistent with the enlightened administration of criminal justice to require the defendant to weigh such pros and cons in deciding whether to testify." Id at 215. Although unitary proceedings remain constitutional under the Fifth Amendment, since McGautha the Supreme Court has held that the bifurcation of the guilt and sentencing proceedings is a significant consideration in determining that a death penalty statute is constitutional. Gregg $v$ Georgia, 428 US 153, 190-92 (1976).

${ }^{33} 425$ US 308 (1976).
} 
the Griffin rule to disciplinary hearings because the stakes are not as high as in criminal trials, and the use of the silence does not constitute as serious a penalty. ${ }^{34}$

Most notably, the Court in Jenkins allowed the prosecution to impeach the defendant's testimony with his prearrest silence, explaining that while such use clearly burdened the exercise of the privilege, the extent of the burden was not impermissible under the dictates of the Fifth Amendment. ${ }^{35}$ Although Griffin, unlike Jenkins, applies to substantive use of a defendant's silence, the Supreme Court's recent treatment of the Griffin "penalty doctrine" may indicate that there is not enough life left in Griffin to support exclusion of a defendant's prearrest silence as evidence of guilt. ${ }^{36}$ Moreover, the Jenkins rule, unlike Griffin, applies specifically to prearrest silence and has not been undercut by the Supreme Court. ${ }^{37}$

Assuming that Griffin is indeed insufficient to support exclusion of prearrest silence as evidence of guilt, the Jenkins "impermissible burden" test provides the most relevant source of analysis for determining whether prosecutorial use of prearrest silence violates the Fifth Amendment. ${ }^{38}$

* Id at 318-19:

In criminal cases, where the stakes are higher and the State's sole interest is to convict, Griffin prohibits the judge and prosecutor from suggesting to the jury that it may treat the defendant's silence as substantive evidence of guilt. Disciplinary proceedings in state prisons, however, involve the correctional process and important state interests other than conviction for crime. We decline to extend the Griffin rule to this context.

See also Stone, $1977 \mathrm{~S} \mathrm{Ct}$ Rev at 147 (cited in note 18) (discussing the Court's treatment of the penalty doctrine in Baxter).

¿s Jenkins, 447 US at 238.

is In Doyle $v$ Ohio, the Supreme Court prohibited impeachment use of postarrest silence. 426 US 610,618 (1976). A straightforward application of Griffin's penalty doctrine would have resolved the issue. See Stone, $1977 \mathrm{~S} \mathrm{Ct}$ Rev at 146-47 (cited in note 18). Under Griffin, if a prosecutor were to use a defendant's postarrest silence against the defendant at trial, the defendant would be improperly punished for exercising her privilege against self-incrimination. Further, the possibility that the defendant might be impeached by her prearrest silence could discourage the defendant from exercising her privilege. However, in Doyle, the Court did not mention Griffin or the Fifth Amendment issues. The Court's failure to rely on Griffin suggests that the penalty doctrine is not sufficiently vital to support exclusion of a defendant's silence outside the courtroom. Instead, the Doyle Court excluded the evidence based upon the Fourteenth Amendment. The Court explained that it would be "fundamentally unfair" and a violation of due process for the police to assure a defendant, via the delivery of Miranda warnings, that her silence would not be used against her, and then allow a prosecutor to introduce the silence at trial. Doyle, 426 US at 618.

${ }^{37}$ Jenkins was subsequently reaffirmed and extended in Fletcher $v$ Weir, 455 US 603 (1982) (holding that the Fifth Amendment does not prohibit a prosecutor from using a defendant's postarrest, pre-Miranda silence to impeach the defendant's testimony at trial).

${ }^{3}$ The Jenkins holding has been criticized in the academic literature. See Poulin, 52 


\section{A. Jenkins and the "Impermissible Burden" Test}

In Jenkins, the Court stated that, although the potential use of prearrest silence may deter a defendant from remaining silent prior to her arrest, "the Constitution does not forbid 'every government-imposed choice in the criminal process that has the effect of discouraging the exercise of constitutional rights." ${ }^{39}$ Instead, the Constitution forbids only those practices that place an "impermissible burden" on the exercise of those rights. Thus, the Court introduced a balancing test that requires courts to determine whether the Constitution forbids a government practice by weighing "the legitimacy of the challenged governmental practice" against "whether compelling the election impairs to an appreciable extent any of the policies behind the rights involved." ${ }^{40}$ Thus, under the impermissible burden test, not every government practice that discourages defendants from remaining silent is unconstitutional.

1. The legitimacy of the challenged governmental practice.

A prosecutor's use of prearrest silence may aid the truthseeking process. As the Jenkins Court explained, it is legitimate for the state to impeach a defendant with her prearrest silence because such impeachment "may enhance the reliability of the criminal process." ${ }^{41}$ The Federal Rules of Evidence permit admission in a criminal trial of all relevant evidence, so long as its probative value exceeds its prejudicial effect. ${ }^{42} \mathrm{~A}$ defendant's prearrest silence may have probative value if the silence is inconsis-

Geo Wash L Rev at 199-200, 214-17 (cited in note 25) (arguing that impeachment use of prearrest silence violates both the Fifth and Fourteenth Amendments); Snyder, 29 Wm \& Mary L Rev at 291-92 (cited in note 16) (arguing that impeachment use of prearrest silence violates the Due Process Clause of the Fourteenth Amendment). But see McKeegan, Note, 46 Albany L Rev at 548-50 (cited in note 11) (arguing, post-Jenkins, that impeachment use of prearrest silence raises no constitutional difficulties). Nonetheless, the Supreme Court reinforced Jenkins in Fletcher, and the two dissenting justices in Jenkins, Marshall and Brennan, are no longer on the Court. Jenkins currently provides the most appropriate framework for determining the constitutionality of prosecutorial use of prearrest silence under the Fifth Amendment.

${ }^{\approx} 447$ US at 236, quoting Chaffin $v$ Stynchcombe, 412 US 17, 30 (1973).

10 Jenkins, 447 US at 236-38, quoting Chaffin, 412 US at 32. Professor Stone has argued that the balancing test advocated by Jenkins is inappropriate in the Fifth Amendment context. See Stone, $1977 \mathrm{~S} \mathrm{Ct}$ Rev at 110-11 (cited in note 18) (explaining that in contrast to the Fourth Amendment exclusionary rule, which is a "court-created device" that calls for balancing to determine admissibility, the Fifth Amendment by its own language mandates the exclusion of evidence obtained in violation of its commands).

${ }^{41} 447$ US at 238 (The Court further explained that "[u]se of such impeachment on cross-examination allows prosecutors to test the credibility of witnesses by asking them to explain prior inconsistent statements and acts.").

12 See FRE 401, 403. 
tent with the position the defendant assumes at trial. In determining whether the prearrest silence is inconsistent, some courts ask whether it would have been "natural" for the defendant to speak up under the circumstances. ${ }^{43}$ For example, if a defendant who has remained silent prior to arrest takes the stand and testifies that she acted in self-defense, the prearrest silence suggests that the defendant is lying if it would have been natural for the defendant to come forward with her defense earlier. Likewise, if a defendant refuses to speak with the police during her prearrest investigation and then pleads innocent at trial, the prearrest silence suggests that the defendant may, in fact, be guilty if it would have been natural for the defendant to have spoken up and proclaimed her innocence early on. ${ }^{44}$ If the prearrest silence does have probative value, and if the probative value exceeds the potential prejudicial effect, admitting the prearrest silence can help the factfinder discover the truth.

2. The impairment of the policies behind the Fifth Amendment.

The Supreme Court's opinion in Murphy $v$ Waterfront Commission represents the Court's most explicit analysis of the traditional rationales supporting the Fifth Amendment privilege. ${ }^{45}$ Two of these traditional policies are particularly relevant to the admissibility of prearrest silence.

First, the Murphy Court relied upon the Fifth Amendment as a means of upholding the values of the adversary system. As the Court explained, the privilege

reflects many of our fundamental values and most noble aspirations ... [including] our preference for an accusatorial rather than an inquisitorial system of criminal justice . . . [and] our sense of fair play which dictates "a fair stateindividual balance by requiring the government to leave the individual alone until good cause is shown for disturbing him and by requiring the government in its contest with the individual to shoulder the entire load."

\footnotetext{
${ }^{4}$ See United States $v$ Hale, 422 US 171, 176-80 (1975), citing John Henry Wigmore, 3A Evidence in Trials at Common Law $\$ 1042$ (Chadbourn rev ed 1970) (prohibiting impeachment use of defendant's pretrial silence on evidentiary grounds).

" However, a defendant's prearrest silence may be probative of many things other than guilt. See notes $49,103-05$, and accompanying text.

378 US 52 (1964).

${ }^{45}$ Id at 55 (citation omitted).
} 
According to this rationale, to preserve a fair balance between the state and the defendant, the prosecution must be forced to prove its case without help from the defendant. ${ }^{47}$

In the context of prearrest silence, allowing prosecutorial use of such silence as evidence of guilt would favor the state in its competition against the individual. If a defendant knows that her prearrest silence may be used against her at trial, she is more likely to speak with the police earlier. The police are accordingly more likely to rely on the defendant as an evidentiary resource and less likely to rely on their own investigation.

Second, the Murphy Court emphasized that the Fifth Amendment was designed to protect the innocent, explaining that "the privilege, while sometimes a 'shelter to the guilty,' is often a 'protection to the innocent."'48 On this view, a defendant may remain silent not because she is guilty, but because she is shy, afraid, or inarticulate. She may have shameful or embarrassing-but not criminal-associations or transactions that she does not want to reveal. ${ }^{49}$ Alternatively, she may have a poor memory and accordingly feel vulnerable to clever interrogation. Although some commentators have endorsed the protect-theinnocent policy, ${ }^{50}$ the Supreme Court has not been consistent in its application of the rationale. On the one hand, the Court re-

${ }^{47}$ Id. See also Doe $v$ United States, 487 US 201, 212-13 (1987) (reaffirming the traditional policies cited in Murphy); Griffin, 380 US at 614 (explaining that prosecutor's comment on defendant's refusal to testify is "a remnant of the inquisitorial system of criminal justice,' which the Fifth Amendment outlaws"), quoting Murphy, 378 US at 55. Although never rejected by the Court, this rationale has been the subject of criticism by academic commentators. See, for example, Alschuler, 94 Mich L Rev at 2669 (cited in note 11) (arguing that "[n]o sensible criminal justice system" would "abandon defendants as an evidentiary resource"); Stephen J. Schulhofer, Some Kind Words for the Privilege Against Self-Incrimination, 26 Valp U L Rev 311, 317-18 (1991) (arguing that there is no good reason for preserving a state-criminal balance because "[t]he criminal process should lead to conviction of the guilty, preferably as quickly and easily as possible, provided of course that other values are not sacrificed").

${ }^{43}$ See Murphy, 378 US at 55, quoting Quinn v United States, 349 US 155, 162 (1954). See also Grunewald v United States, 353 US 391, 421 (1957) ("[O]ne of the basic functions of the privilege is to protect innocent men.").

${ }^{49}$ The Fifth Amendment does not protect privacy; it protects only against revelations of self-incriminatory information. See Fisher $v$ United States, 425 US 391, 401 (1976) (internal quotation marks omitted):

We cannot cut the Fifth Amendment completely loose from the moorings of its language, and make it serve as a general protector of privacy-a word not mentioned in its text and a concept directly addressed in the Fourth Amendment. We adhere to the view that the Fifth Amendment protects against compelled self-incrimination, not [the disclosure of] private information.

${ }^{50}$ See, for example, Schulhofer, 26 Valp U L Rev at 330-32 (cited in note 47) ("[O]nce we recognize that some criminal defendants who prefer silence may be innocent, a decision to compel their potentially unreliable testimony involves not only the ever-present risk of convicting the innocent, but also a serious problem of fairness."). 
cently reaffirmed the traditional policies cited in Murphy, including the policy of employing the Fifth Amendment to protect the innocent. ${ }^{51}$ In contrast, the Court has at times repudiated the protect-the-innocent rationale. In Tehan $v$ Shott, for example, the Court declared that "the basic purposes that lie behind the privilege against self-incrimination do not relate to protecting the innocent from conviction." 52

Although the Tehan Court did not explain why it rejected the protect-the-innocent rationale, it may have been motivated by a concern that the Fifth Amendment, in practice, actually may undermine protection of the innocent. As one commentator has explained, a jury is likely to regard a defendant's failure to testify as evidence of guilt. ${ }^{53}$ If this is the case, a jury may view the defendant who does not testify in a worse light than the defendant who testifies poorly. According to this view, the Fifth Amendment discourages the innocent defendant from testifying at trial by shielding her from the normal incentives to speak up and clear her name. Innocent defendants will instead remain silent and, thanks to negative jury inferences, run an increased risk of conviction. ${ }^{54}$

Third, the Fifth Amendment may be employed, much as the Fourth Amendment exclusionary rule has been employed, to deter police misconduct. ${ }^{55}$ As one state supreme court has opined, if the police know that a defendant's prearrest silence is available for use at trial and the postarrest silence is not, the police have incentives to manipulate the time of arrest and delivery of the Miranda warnings to ensure that the defendant's silence in the face of accusation is admissible. ${ }^{56}$

"See Doe, 487 US at $212-13$, citing Murphy, 378 US at 55 ("[T]he privilege . . . is often a "protection to the innocent.").

${ }_{62} 382$ US 406, 415 (1966). The Court noted that the purpose is "rather to preserv[e] the integrity of a judicial system in which even the guilty are not to be convicted unless the prosecution shoulder the entire load." Id (internal quotation omitted).

${ }^{{ }_{2}}$ Lisa Tarallo, Note, The Fifth Amendment Privilege Against Self-Incrimination: The Time Has Come for the United States Supreme Court to End Its Silence on the Rationale Behind the Contemporary Application of the Privilege, 27 New Eng L Rev 137, 166 (1992).

${ }^{4}$ See id. See also Report to the Attorney General on Adverse Inferences from Silence, $22 \mathrm{U}$ Mich J L Ref 1005, 1011 (1989) (criticizing the protect-the-innocent rationale).

${ }^{5}$ See, for example, Mapp v Ohio, 367 US 643, 656 (1961) ("[T]he purpose of the exclusionary rule is to deter-to compel respect for the constitutional guaranty in the only effectively available way-by removing the incentive to disregard it."), quoting Elkins $v$ United States, 364 US 206, 217 (1960).

${ }^{56}$ Tortolito $v$ Wyoming, 901 P2d 387, 390-91 (Wyo 1995) (relying on the Wyoming Constitution's privilege against self-incrimination to prohibit prosecutorial comment on a non-testifying defendant's prearrest silence). See also State v Easter, 130 Wash 2d 228, 922 P2d 1285, 1290 (1996) (prohibiting substantive use of prearrest silence). 
Although the Murphy Court did not include a deterrence rationale among its traditional policies behind the Fifth Amendment, since Murphy, the Court has invoked this rationale. For example, in Harris $v$ New York, ${ }^{57}$ the Court allowed the prosecutor to use statements obtained in violation of the Miranda safeguards for impeachment purposes. In reaching this conclusion, the Court applied the exclusionary rule and held that it was unnecessary to exclude the evidence for deterrence purposes. Holding that the self-incriminatory evidence would be available only for impeachment and not for substantive use, the Harris Court explained that exclusion of the evidence was unnecessary because "sufficient deterrence flows when the evidence in question is made unavailable to the prosecution in its case in chief." Such a rationale supports impeachment use alone; if prearrest silence is available for both impeachment and substantive use, no such constraints would bind the police. ${ }^{59}$

\section{B. Distinguishing Substantive from Impeachment Use of Prearrest Silence}

Although Jenkins endorses prosecutorial use of prearrest silence, the holding is limited to impeachment use. ${ }^{60}$ The Court explicitly left open the constitutionality of prosecutorial use of prearrest silence as evidence of guilt, and has not subsequently resolved the issue. ${ }^{61}$ As this Part demonstrates, the Court has long acknowledged that impeachment use implicates additional concerns beyond the policies behind the Fifth Amendment. Thus, in light of these additional concerns, the impermissible burden test set forth in Jenkins must be applied anew to determine the constitutionality of the use of prearrest silence as substantive evidence of guilt. ${ }^{62}$

When a prosecutor seeks to admit a defendant's prearrest silence into her case-in-chief, the traditional policies behind the

${ }^{57} 401$ US 222 (1971).

ss Id at 225.

${ }^{69}$ For further discussion, see Part IN.B.2.

${ }^{\infty} 447$ US at 238.

${ }^{61}$ See note 5 .

${ }^{62}$ The law has long distinguished between impeachment and substantive use of proffered evidence. For example, under the Federal Rules of Evidence, if the prior inconsistent statement of an available witness is used as substantive evidence, the prior statement must have been made under oath and at a prior hearing or deposition. FRE 801(d)(1)(A). In contrast, if the prior statement is offered only to impeach the defendant's credibility, the oath and hearing requirements need not be met. FRE 613. It is thus easier for a party seeking admission of a prior inconsistent statement to get the statement into evidence for impeachment than for substantive use. 
Fifth Amendment are implicated. ${ }^{63}$ When, however, the prosecutor seeks to use the same silence to impeach a defendant's trial testimony, considerations beyond those traditional concerns are called into play. Because of the additional considerations implicated by impeachment use, the Supreme Court has long been willing to admit evidence for impeachment that would not otherwise be admissible in the prosecutor's case-in-chief. ${ }^{64}$

First, impeachment use addresses concerns about perjury that are not at issue when the defendant does not take the stand. This consideration guided the Supreme Court's decision in Harris $v$ New York, ${ }^{65}$ in which the Court faced a defendant whose testimony on direct examination contradicted statements he allegedly made to police following his arrest, but without the benefit of valid Miranda warnings. Although the Court acknowledged that the statements would be inadmissible in the prosecutor's case-inchief, the Court, clearly concerned about the need to test the defendant's credibility, held that the prosecutor could use the statements to impeach the defendant. ${ }^{66}$ As the Harris Court explained, "[e]very criminal defendant is privileged to testify in his own defense, or to refuse to do so. But that privilege cannot be construed to include the right to commit perjury. ${ }^{n 67}$

Second, impeachment use has long been justified on the ground that when a defendant chooses to testify, he waives his privilege against self-incrimination. As long ago as 1926, the Court, in Raffel $v$ United States ${ }^{68}$ relied on this so-called "waiver rule" to allow the prosecution to use a defendant's failure to testify at his first trial to impeach his testimony at his second trial. $^{69}$ The Court maintained that "[t]he safeguards against selfincrimination are for the benefit of those who do not wish to become witnesses in their own behalf and not for those who do."70

${ }^{a}$ See Murphy, 378 US 52, and text accompanying notes 45-54.

4 See Walder $v$ United States, 347 US 62 (1964) (holding that the prosecutor may use evidence that was inadmissible in the defendant's prior trial to impeach the defendant's testimony at trial, but only because the defendant had "opened the door" and the evidence was being used for purposes of attacking the defendant's credibility); Harris $v$ New York, 401 US 222 (1971) (expanding the Walder exception to hold that evidence otherwise inadmissible in the defendant's present trial-because it was obtained in violation of the Miranda dictates-is admissible to impeach the defendant's credibility); Oregon $v$ Hass, 420 US 714, 723-24 (1975) (allowing impeachment use of statements obtained in egregious violation of Miranda dictates, even though such statements would not be available as substantive evidence of guilt).

${ }^{65} 401$ US 222 (1971).

${ }^{65}$ Id at 224.

${ }^{67}$ Id at 225.

6* 271 US 494 (1926).

${ }^{6}$ Id at 499.

${ }^{\text {so Id. }}$ 
Accordingly, once the defendant had made the decision to take the stand, he had waived his Fifth Amendment privilege and could not subsequently reassert the privilege when the prosecutor's questions proved "inconvenient or embarrassing." irrevocably opened himself up to cross-examination on his failure to speak up at the earlier trial.

The Supreme Court reaffirmed the Raffel holding in Jenkins. ${ }^{72}$ If the defendant does not testify, however, she cannot be deemed to have waived her Fifth Amendment privilege, and thus the Raffel justification for impeachment use does not apply. Indeed, in Raffel, the Court suggested that if the defendant had chosen not to testify at the second trial, his silence at his first trial would have been inadmissible. ${ }^{73}$

Third, the availability of impeachment use is less likely to discourage a defendant from exercising his Fifth Amendment privilege than the availability of substantive use. In Chaffin $v$ Stynchombe, the Supreme Court referred to this phenomenon as the "chilling effect." If incriminating evidence is admissible only for impeachment use, a defendant who wishes to avoid having the proffered evidence introduced may do so by declining to testify. If, on the other hand, the evidence is admissible for both impeachment and substantive use, the defendant is unable to avoid its introduction. The defendant is thus less likely to remain silent prior to arrest and more likely to speak to the police at the first opportunity. Substantive use of prearrest silence is thus more likely to "chill" a defendant's decision to exercise her privilege against self-incrimination than is impeachment use.

\section{Jenkins misapplied.}

The Supreme Court's careful distinction between impeachment and substantive use of prearrest silence calls for separate applications of the Jenkins impermissible burden test. Some lower courts have failed to undertake this separate application

${ }^{71}$ Id at 497. See also Harris, 401 US at 225 (allowing impeachment use of statements made in custody but absent Miranda warnings, because "[h]aving voluntarily taken the stand, petitioner was under an obligation to speak truthfully and accurately, and the prosecution here did no more than utilize the traditional truth-testing devices of the adversary process.") (emphasis added).

7247 US at $240-41$.

${ }^{73}$ See Raffel, 271 US at 497 ("We may concede, without deciding, that if the defendant had not taken the stand on the second trial, evidence that he had claimed the same immunity on the first trial would be probative of no fact in issue, and would be inadmissible.").

*4 412 US 17, 33 (1972). 
and instead have simply extended Jenkins to admit prearrest silence as evidence of guilt.

In United States $v$ Rivera, ${ }^{75}$ the prosecutor introduced evidence in its case-in-chief that the defendant had remained silent during the prearrest investigation. The prosecutor used the prior silence not to impeach the defendant's credibility-the defendant failed to testify at trial-but as substantive evidence of the defendant's guilt. On appeal, the Eleventh Circuit upheld the use of prearrest silence as evidence of guilt. ${ }^{76}$ The court supported its holding with a reference to Jenkins, but failed to note that Jenkins applies specifically to impeachment use and leaves open the propriety of substantive use of prearrest silence. ${ }^{77}$ Despite this apparent misapplication of the Jenkins rule, the Eleventh Circuit has held fast to Rivera and made clear that its holding extends to substantive use of prearrest silence. ${ }^{78}$

\section{Jenkins properly applied.}

In contrast, the First and Seventh Circuits have acknowledged that Supreme Court precedent requires that courts distinguish between impeachment and substantive use of prearrest silence. ${ }^{79}$ In Coppola $v$ Powell, the defendant told the police, prior to his arrest, that he was not going to confess and was unwilling to speak further without his lawyer present. ${ }^{80}$ The First Circuit held that since the defendant did not testify at trial, the prosecution could not use the prearrest silence for impeachment pur-

75 944 F2d 1563 (11th Cir 1991).

${ }^{70}$ Id at 1568-70 ("The government may comment on a defendant's silence if it occurred prior to the time that he is arrested and given his Miranda warnings ... [or] when it occurs after arrest, but before Miranda warnings are given.").

7 Id at 1568. See also Jenkins, 447 US at $236 \mathrm{n} 2$.

See, for example, United States $v$ Simon, 964 F2d 1082, $1086 \mathrm{n} *$ (11th Cir 1992) (explaining Rivera to allow use of defendant's prearrest silence in government's case-inchief); United States v Tenorio, 69 F3d 1103, 1108 (11th Cir 1995) (Edmondson concurring) (explaining that "[t]he law of this circuit is settled that evidence of pre-Miranda silence is admissible in the government's case-in-chief as substantive proof of guilt'). The Fifth Circuit has also held that substantive use of prearrest silence does not violate the Fifth Amendment. See United States v Zanabria, 74 F3d 590 (5th Cir 1996). In Zanabria, the defendant did not testify at trial. Nonetheless, the court allowed the prosecution to introduce the defendant's prearrest silence to rebut the testimony of a defense witness. The witness testified that the defendant had committed the crime of which he was accused, but that he had acted under duress. The court allowed the prosecution to use the defendant's prearrest silence against him by suggesting to the jury that, if the defendant had indeed acted under duress, he would have offered his defense when initially questioned by the police. Id at 593. Although the Zanabria court did not cite Jenkins, the court was most likely influenced by the perjury-prevention rationale that guides the impeachment line of cases.

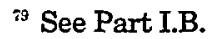

so 878 F2d 1562, 1565-66 (1st Cir 1989). 
poses because there was nothing to impeach. ${ }^{81}$ Likewise, in Savory, the Seventh Circuit did not allow the prosecution to use the defendant's prearrest refusal to answer police inquiries as evidence of guilt, since he did not testify at the trial. ${ }^{82}$ The Savory court distinguished between impeachment cases, in which the defendant "opens himself to impeachment by taking the stand," and the case before it, in which the defendant did not. ${ }^{83}$

\section{APPLYING THE IMPERMISSIBLE BURDEN TEST TO THE USE OF PREARREST SILENCE FOR IMPEACHMENT}

In Jenkins, the Supreme Court applied the impermissible burden test to establish that if a defendant remains silent prior to arrest and subsequently testifies at trial, the prosecution may use that defendant's prearrest silence for impeachment purposes. ${ }^{84}$

The Jenkins Court first asked whether impeachment use of prearrest silence "impairs to an appreciable extent any of the policies behind the rights involved." The Court did not, however, discuss what it believed the pertinent policies to be. ${ }^{85}$ Instead, the Court discussed three concerns that have, in the past, guided its decisions to admit evidence to impeach a defendant's credibility, even though the evidence would be inadmissible as substantive evidence of guilt. ${ }^{86}$ First, the Court discussed the potential "chilling effect" of impeachment use of prearrest silence on a defendant's decision to testify at trial. The Court relied on its holding in Raffel, in which the Court held that a prosecutor may use a defendant's failure to testify at his first trial to impeach him at his second trial, even though the silence at the first trial would most likely not have been admissible as substantive evidence of guilt. ${ }^{87}$ Concluding that the possibility of impeachment

${ }^{31}$ Id at 1567-68.

82832 F2d at 1018-20. Relying on Griffin, the Tenth Circuit reached a similar conclusion in United States $v$ Burson, 952 F2d 1196, 1201 (10th Cir 1991).

${ }^{*}$ Savory, 832 F2d at 1017-18 (citing Jenkins and Fletcher and reasoning that "[t]he cases which have allowed impeachment by silence rely on the fact that the defendant opens himself to impeachment by taking the stand. . . There is, on the other hand, a constitutional right to say nothing at all about the allegations.").

\& 447 US at 238. One scholar has criticized the Court's conclusion in Jenkins, arguing that impeachment use of prearrest silence does, in fact, impermissibly burden the Fifth Amendment privilege. See Poulin, 52 Geo Wash L Rev at 215-17 (cited in note 25).

\&s 447 US at 236. Thus, in the absence of clear guidance by the Jenkins Court, courts should consider the traditional policies behind the Fifth Amendment in determining whether a prosecutor may constitutionally use a defendant's prearrest silence as evidence of guilt. See Part IV.B.

${ }^{86}$ See Part II.B.

${ }^{87}$ Jenkins, 447 US at 235-36, citing Raffel, 271 US at $496-97$. 
by prior silence does not substantially discourage a defendant from taking the stand, the Jenkins Court explained, "[w]e are unable to see that the rule that [an accused who] testifies ... . must testify fully, adds in any substantial manner to the inescapable embarrassment which the accused must experience in determining whether he shall testify or not." ${ }^{\text {s8 }}$

Second, the Court relied again on Raffel and evoked the Raffel waiver rule. The waiver rule holds that when a defendant takes the stand, she waives her privilege against selfincrimination and cannot subsequently reassert it simply because a prosecutor's questions, upon cross-examination, become "inconvenient or embarrassing." ${ }^{89}$ Following Raffel, the Jenkins Court emphasized the defendant's voluntary "decision to cast aside his cloak of silence" and testify. ${ }^{90}$ Citing the principle that the privilege against self-incrimination protects only those persons who actually assert their Fifth Amendment rights, the Court held that the defendant in Jenkins in fact cast aside his Fifth Amendment rights by voluntarily taking the stand on his own behalf. Thus the defendant waived his privilege against selfincrimination. ${ }^{91}$

Third, the Court emphasized the role of the trial as a truthseeking process and the need for impeachment to prevent perjury by the defendant. The Court relied on its holding in Harris, where it had allowed a defendant's statements taken in violation of Miranda to be used to impeach the defendant's testimony at trial-even though the statements would be inadmissible as evidence of guilt. ${ }^{92}$ As it had in Harris, the Jenkins Court admitted otherwise inadmissible evidence for the sole purpose of challenging a defendant's testimony at trial, to ensure that he spoke "truthfully and accurately" and did not perjure himself on the stand. ${ }^{93}$

Undertaking the other half of the balancing test, the Jenkins Court next looked at the legitimacy of the challenged government practice, and found that impeachment use of prearrest silence is a legitimate practice because it may "enhance the reliability of the criminal process." ${ }^{\prime 94}$ According to the Court's reasoning, the Jenkins rule enables a prosecutor to "test the credibility of wit-

\footnotetext{
sx Jenkins, 447 US at 237, citing Raffel, 271 US at 499.

§9 Jenkins, 447 US at 236-37. See also Raffel, 271 US at 497.

"Jenkins, 447 US at 238.

${ }^{91}$ Id at 235-36.

:2 Id at 237-38, citing Harris, 401 US at 225.

s3 Jenkins, 447 US at 238.

^ Id at 238.
} 
nesses by asking them to explain prior inconsistent statements and acts." ${ }^{.95}$ For example, if a defendant remains silent prior to arrest and later testifies that she acted in self-defense, Jenkins enables the prosecutor to challenge her testimony with the suggestion that the prearrest silence may be inconsistent with the proffered defense.

\section{APPLYING THE IMPERMISSIBLE BURDEN TEST TO PROSECUTORIAL USE OF PREARREST SILENCE AS EVIDENCE OF GUIIT}

Although Jenkins provides a test for determining the constitutionality of admitting prearrest silence, the Jenkins holding is limited to impeachment use. ${ }^{96}$ This Part demonstrates that, under the Jenkins balancing test, the prosecutor should not be able to use the defendant's prearrest silence as substantive evidence of guilt. ${ }^{97}$

\section{A. The Legitimacy of the Government Practice}

Assuming that the probative value of prearrest silence exceeds its prejudicial effect, use of silence can be a legitimate government practice if it aids the factfinder in discovering the truth, thus enhancing the reliability of the criminal process. ${ }^{98}$ The Jenkins Court found that impeachment use of prearrest silence does aid the factfinder in discovering the truth. ${ }^{99}$ The Court ex-

\footnotetext{
${ }^{2}$ Id.

${ }^{96}$ Id at $236 \mathrm{n} 2$ (explaining that the Court's decision is limited to impeachment use).

${ }^{97}$ Assuming the impermissible burden model dictates that the Fifth Amendment protects against substantive use of prearrest silence, as this Comment argues it does, there remains a question of whether a defendant who does not affirmatively assert the right adequately invokes the privilege. For example, if a defendant leaves the scene of a crime and then waits two weeks before coming forward to tell the police her story, may the prosecutor introduce the defendant's two weeks of silence on the grounds that she never invoked her privilege against self-incrimination? A requirement that the defendant affirmatively claim the privilege would create a distinction between the cases where the defendant faces prearrest questioning (and has an opportunity explicitly to exercise the privilege), and the cases where she does not (and the silence at issue is a failure to come forward and present herself to the police). Although the Supreme Court has long held that there is no duty to report criminal wrongdoing, suggesting that the invocation requirement should not be strictly applied to a defendant's failure to come forward, such a discussion is beyond the scope of this Comment. For more extensive discussion of the invocation requirement, compare McKeegan, Note, 46 Albany $L$ Rev at 557-65 (cited in note 11) (arguing that a prosecutor may use a defendant's prearrest silence if the Fifth Amendment privilege is not affirmatively invoked), with Poulin, 52 Geo Wash L Rev at 225-26 (cited in note 25) (rejecting McKeegan's explicit invocation model as providing insufficient protection for a defendant's constitutional rights).

${ }^{93}$ See Part II.A.1.

s9 Jenkins, 447 US at 238.
} 
plained that impeachment is a "traditional truth-testing device" that allows a prosecutor to challenge the credibility of a witness by asking her to explain prior inconsistent statements and facts. ${ }^{100}$ Thus, when a defendant takes the stand, it is proper to test her credibility by asking that she explain the inconsistency between her prearrest silence and her testimony at trial. The Jenkins Court acknowledged, however, that a defendant may decide against taking the stand because of the risk of crossexamination. ${ }^{101}$ If the defendant does not take the stand, she is not a witness, and therefore her credibility is not at issue in the case. ${ }^{102}$ Absent a witness whose credibility must be tested, the value of the prearrest silence as a means of obtaining the truth is diminished.

If the defendant does not testify, the only remaining use of the prearrest silence is to suggest guilt. Although there are circumstances in which prearrest silence may be probative of guilt, it can only minimally advance the search for truth. Prearrest silence is of limited help to truth-seeking because there are many reasons why one cannot reasonably infer guilt from prearrest silence. As New York's highest court has explained, "it is an unfortunate truth that many people in our society, especially those involved in the life of the street, view the police as antagonists rather than protectors and react to police contact with extreme suspicion, distrust, and lack of cooperation." ${ }^{\text {"03 }}$ Police interrogation is an intimidating prospect to both the guilty and the innocent. The presence of the police-or the nature of their inquiries-may shock, frighten, or confuse the defendant. Alternatively, she may believe it useless to justify her apparently criminal behavior. She might remain silent not because she is guilty but because she fears the police will not believe her story. Or she may be involved in unrelated associations or transactions that she does not want to reveal to the police. These may be noncriminal matters that she wants to keep private or that she fears will make her look bad, or they may be criminal matters unrelated to the crime under investigation. ${ }^{104}$ These explanations dic-

\footnotetext{
${ }^{10} \mathrm{Id}$.

${ }^{101} \mathrm{Id}$.

${ }^{122}$ See State $v$ Easter, 130 Wash 2d 228, 922 P2d 1285, 1290 (1996) (In prohibiting substantive use of prearrest silence, the court explained that a nontestifying defendant's credibility is not at issue and thus the impeachment line of cases does not control.).

${ }^{13}$ People $v$ Conyers, 49 NY2d 174, 424 NYS2d 402, 408, vacated as New York $v$ Conyers, 449 US 809 (1980) (for reconsideration in light of Jenkins), original decision upheld, 52 NY2d 454, 438 NYS2d 741 (1981).

${ }^{20}$ If a defendant remains silent because she is involved in other, unrelated criminal matters, her silence still should not be used against her, because such use risks convict-
} 
tate that the silence, if not completely unambiguous, will be of little help to the factfinder in determining guilt or innocence. ${ }^{105}$

B. The Impairment of the Policies Behind the Fifth Amendment

Undertaking the second half of the balancing test, any minimal aid to truth-seeking must be weighed against the extent to which substantive use of prearrest silence impairs the policies behind the Fifth Amendment. In describing the balancing test, the Jenkins Court did not explain what it believed those policies to be. Instead, the Court based its holding on additional considerations that have limited application to substantive use of prearrest silence. Because the concerns cited by Jenkins do not apply to substantive use, and in the absence of clear guidance from the Jenkins Court, courts should rely on the traditional justifications for the Fifth Amendment protections in applying the balancing test.

1. The policies that support impeachment use of prearrest silence.

In allowing prosecutors to use prearrest silence for impeachment purposes, the Jenkins Court was guided by three main considerations: (1) the likelihood that the possibility of impeachment by prearrest silence will discourage the defendant from testifying; (2) the defendant's decision to waive his privilege against self-incrimination; and (3) the need for impeachment to prevent perjury by the defendants. ${ }^{106}$ These considerations, however, do not support a finding that substantive use of a defendant's prearrest silence is permissible.

The Jenkins Court first asked whether impeachment by prior silence would substantially discourage a defendant from taking the stand. This consideration is unlikely to be implicated in a substantive use case. If substantive use of prearrest silence is permissible, the prosecutor may introduce the evidence whether or not the defendant decides to testify. This invariable availability of the evidence means that the possibility that the prosecutor will introduce the prearrest silence is unlikely to discourage the defendant from taking the stand.

In contrast, the availability of substantive use of prearrest silence is more likely to discourage a defendant from asserting

ing her for a crime she did not commit.

${ }^{105} \mathrm{~A}$ defendant may also remain silent in reliance on her knowledge of the Miranda warnings. See note 16.

${ }^{100}$ Jenkins, 447 US at 236-38. 
her privilege against self-incrimination prior to arrest than is the availability of impeachment use. If the prearrest silence is admissible only for impeachment use, a defendant who wishes to avoid having the silence introduced may do so by declining to testify. If, on the other hand, the evidence is admissible for both impeachment and substantive use, the defendant is unable to avoid its introduction. The defendant is thus less likely to remain silent prior to arrest, and more likely to speak to the police at the first opportunity. Substantive use of prearrest silence is thus more likely to "chill" a defendant's decision to exercise her privilege against self-incrimination than is impeachment use.

The second consideration-the defendant's choice to testify and thus waive the privilege-is also unlikely to be implicated in a substantive use case. In each of the cases that make up the circuit split, the defendant chose not to take the stand. ${ }^{107}$ If the defendant does not take the stand, she cannot be said to have voluntarily given up her silence and waived the privilege against self-incrimination. In fact, by refusing to testify, she presumably continues to assert her Fifth Amendment rights.

The third consideration-the need for impeachment use to prevent perjury-is also unlikely to be at issue in a substantive use case. If the defendant does not take the stand, she chooses not to speak before the court, and thus cannot perjure herself. However, abuse of the truth-seeking process may be implicated in a substantive use case if the defendants, during prearrest questioning, selectively answer police questions and then seek to have their refusal to answer certain questions excluded on Fifth Amendment grounds.

A concern about defendants improperly impeding the truthseeking process led the Seventh Circuit to modify its general prohibition against admitting prearrest silence as evidence of guilt. In United States v Davenport, ${ }^{108} \mathrm{Mr}$. and Mrs. Davenport, who were ultimately tried for money laundering, selectively answered questions put to them by IRS agents during a prearrest interrogation. ${ }^{109}$ During pretrial questioning, they responded

\footnotetext{
${ }^{107}$ See Coppola, 878 F2d 1562; Savory, 832 F2d 1011; Rivera, 944 F2d 1563; United States v Zanabria, 74 F3d 590 (5th Cir 1996); United States $v$ Burson, 952 F2d 1196 (10th Cir 1991).

1"929 F2d 1169 (7th Cir 1991).

${ }^{109}$ Id at 1173-75. The court found that, although the Davenports had not been arrested at the time they were questioned, they had received valid Miranda warnings. Id at 1171. The Davenport holding has since been construed as a modification of the Seventh Circuit's prohibition in Savory against admitting prearrest silence as evidence of guilt. See United States $v$ Collins, 972 F2d 1385, 1409 n 49 (5th Cir 1992) (concluding that Davenport 'limited [Savory $v$ ] Lane's scope to those situations in which the defendant is com-
} 
when it favored their claims of innocence to do so, but refused to answer when the evidence sought might incriminate them. For example, the agents asked Mrs. Davenport where she obtained the money at issue. She explained that she and her husband had inherited the money from his father, ${ }^{110}$ but when the agents asked for the father's name Mrs. Davenport refused to divulge it. ${ }^{111}$ The defendants did not testify at trial, so the prosecutor had no opportunity to ask Mrs. Davenport why, if she was telling the truth during prearrest questioning, she was unwilling to provide her father-in-law's name. Instead, at trial, one agent testified to the fact that Mrs. Davenport claimed the defendants had inherited the money from her father-in-law but refused to give the father-in-law's name so that the agents could check the defendant's alibi. ${ }^{112}$ The Seventh Circuit held that the prosecution may use a defendant's decision to answer some but not all of the questions against the defendant at trial. The court explained, "The privilege against self-incrimination is not a privilege to attempt to gain an advantage in the criminal process, whether in its investigation or its trial stage, by selective disclosure followed by a clamming up."113 For this reason, the Davenport court limited exclusion to cases where the defendant is completely silent prior to arrest. ${ }^{114}$

The Supreme Court has expressed concern about letting defendants play games with the truth. ${ }^{115}$ Where there is no evidence, however, that the defendant is manipulating the truthseeking process by means of selective prearrest silence, the concerns articulated in the Davenport and Jenkins decisions are not at work, and prearrest silence should not be admissible.

pletely silent, as opposed to situations in which the defendant answers some questions and then refuses to answer others."). Further, the court's concerns in Davenport are applicable in the context of pre-Miranda silence.

${ }^{110} 929 \mathrm{~F} 2 \mathrm{~d}$ at 1171.

$111 \mathrm{Id}$ at 1173 .

${ }^{112}$ Id at $1173-74$.

${ }^{113}$ Id at $1174-75$.

${ }^{114} \mathrm{Id}$ at 1174.

${ }^{115}$ See Harris, 401 US at 224-25, quoting Walder $v$ United States, 347 US 62,65 (1954) (arguing that while "the Government cannot make an affirmative use of evidence unlawfully obtained ... the defendant [cannot] turn the illegal method by which evidence in the Government's possession was obtained to his own advantage, and provide himself with a shield against contradiction of his untruths"). 
2. The policies that are violated by substantive use of prearrest silence.

In describing the balancing test, the Jenkins Court did not explain what it believed to be the policies behind the Fifth Amendment. Instead, the Court cited three considerations that, if the defendant does not testify, do not apply to a court's analysis of whether prearrest silence should be admitted. In the absence of clear guidance from the Jenkins Court, courts should look to the traditional justifications for the Fifth Amendment protections in applying the balancing test. Three of those justifications are particularly appropriate in the context of prearrest silence: (1) the need to deter improper police behavior; ${ }^{116}$ (2) the need to protect the values of the adversary system; ${ }^{117}$ and (3) the need to protect the innocent from wrongful conviction. ${ }^{118}$

First, admitting prearrest silence as evidence of guilt would encourage police misconduct. The police know, after Doyle $v$ Ohio, ${ }^{119}$ that a defendant's silence following arrest and receipt of Miranda warnings is inadmissible. If the police also knew the state could use prearrest and pre-Miranda silence, the police would have an incentive to manipulate the time of arrest and the delivery of Miranda warnings until after the suspect remains silent in the face of accusation, in order to be able to use the prearrest silence against her. ${ }^{120}$ Excluding a defendant's prearrest silence from evidence thus removes the incentive to police to delay delivery of the Miranda warnings.

However, the Jenkins Court allowed impeachment use of prearrest silence, apparently concluding that the threat of police overreaching was not sufficiently troublesome to bar the use of prearrest silence for impeachment purposes. Such a conclusion applies to impeachment use alone. When evidence is available for both impeachment and substantive use, the likelihood of police misconduct increases. In Harris, the Supreme Court acknowledged that there is a greater risk of police abuse when the proffered evidence is being used for substantive rather than impeachment purposes. The Harris Court allowed the prosecutor to impeach the defendant with statements obtained in violation of his Miranda rights, reasoning that "sufficient deterrence flows when the evidence in question is made unavailable to the prose-

\footnotetext{
${ }^{116}$ Harris, 401 US at 224-25. See also text accompanying notes 55-59.

${ }^{117}$ Murphy, 378 US at 55. See also notes $46-47$ and accompanying text.

${ }^{118}$ Murphy, 378 US at 55. See also notes $48-54$ and accompanying text.

${ }^{15} 426$ US 610 (1976) (prohibiting use of post-Miranda silence).

${ }^{12}$ For a discussion of the deterrence rationale as it relates to substantive use of prearrest silence, see Tortolito $v$ Wyoming, $901 \mathrm{P} 2 \mathrm{~d} 387,390-91$ (Wyo 1995).
} 
cution in its case in chief." ${ }^{121}$ Such a rationale supports impeachment use alone; if prearrest silence is available for both impeachment and substantive use, no such constraints would bind the police.

In the context of prearrest silence, the police do not know prior to arrest whether or not the defendant will testify. If the silence is available only for impeachment use, the police have incentives to deliver properly the Miranda warnings. If they delay the warnings until after the defendant has remained silent in the face of interrogation and the defendant chooses not to testify, then the prosecutor will be unable to use the silence against the defendant. If, however, silence is admissible for both substantive and impeachment use, the police have no such incentives to behave properly. They can manipulate the time of arrest and delivery of the Miranda warnings without fear that the defendant's prearrest silence will be rendered inadmissible.

Second, admitting prearrest silence as evidence of guilt would undermine the traditional values at the foundation of the adversary system. Indeed, the Griffin Court prohibited comment on a defendant's failure to testify at trial on the ground that such a prohibition serves the values of the adversary system. ${ }^{122}$ Similarly, if a defendant knows her prearrest silence may be used against her, she is more likely to speak with the police, encouraging police reliance on defendants as a source of evidence. An accusatorial system, in contrast to an inquisitorial system, demands that the state employ its substantial power to investigate and prove its case. An accusatorial system discourages police reliance on defendants as a source of evidence, because such reliance threatens to give rise to improper police conduct. Excluding prearrest silence as substantive evidence of guilt furthers the values of the accusatorial system because if silence is excluded, the defendant is less likely to speak, the police are forced to investigate, and the prosecution is forced to prove its case, without help from the defendant. Thus, a proper balance is maintained in the individual's competition with the state.

Third, admitting prearrest silence as substantive evidence of guilt may lead to faulty convictions. For this reason, the Griffin Court prohibited the prosecutor from commenting on a defendant's failure to testify at trial, on the ground that the Fifth

${ }^{221}$ Harris, 401 US at 225.

${ }^{122}$ Griffin, 380 US at 614, quoting Murphy, 378 US at 55 ("[C]omment on the refusal to testify is a remnant of the 'inquisitorial system of criminal justice,' which the Fifth Amendment outlaws."). 
Amendment must be employed to protect the innocent. ${ }^{123} \mathrm{Al}-$ though the Supreme Court appears to have retreated somewhat from this rationale, ${ }^{124}$ diminishing its value to the impermissible burden test, it remains compelling in the context of admitting prearrest silence as evidence of guilt. As discussed above, there are several legitimate reasons why an innocent defendant might remain silent prior to arrest. ${ }^{125}$ The defendant may, of course, choose to testify in her own defense and explain her reasons. In fact, when threatened with the prosecution's use of the prearrest silence, the defendant is under pressure to take the stand. Since a defendant easily disturbed prior to arrest is likely to make a poor witness, the defendant may be unable to exculpate herself. The prosecutor's use of prearrest silence as evidence of guilt thus threatens to convict the innocent. ${ }^{126}$

\section{CONCLUSION}

Prosecutorial use of a defendant's prearrest silence as evidence of guilt violates the Fifth Amendment. Some courts have properly barred the use of prearrest silence as evidence of guilt, by relying on Griffin $v$ California. Although the Supreme Court has never explicitly limited Griffin to in-court silence, the Court's current approach the Fifth Amendment suggests that the Griffin "right to silence" is outdated. Instead, the Court has indicated that the appropriate method for analyzing the constitutionality of prearrest silence is the "impermissible burden" balancing test, which requires a court to weigh the legitimate purpose of the prosecution's use of silence against the extent to which such use impairs the policies behind the Fifth Amendment. Although the Jenkins Court applied this test to hold that impeachment use of prearrest silence does not violate the Constitution, the rationales supporting the Jenkins rule do not support the use of prearrest silence as evidence of guilt. Applying the balancing test to sub-

\footnotetext{
${ }^{123}$ See Griffin, 380 US at 613, quoting Wilson v United States, 149 US 60, 66 (1892), disallowing prosecutorial comment on a defendant's failure to testify at trial because

[i]t is not every one who can safely venture on the witness stand though entirely innocent of the charge against him. Excessive timidity, nervousness when facing others and attempting to explain transactions of a suspicious character, and offences charged against him, will often confuse and embarrass him to such a degree as to increase rather than remove prejudices against him.

${ }^{12}$ See notes 50-54 and accompanying text.

${ }^{125}$ See notes 49, 103-05 and accompanying text.

${ }^{126}$ For further discussion of the protect-the-innocent rationale as applied to substantive use of prearrest silence, see Poulin, 52 Geo Wash L Rev at 212 (cited in note 25).
} 
stantive use demonstrates that a prosecutor cannot legitimately use a defendant's prearrest silence in her case-in-chief.

Evidentiary use of prearrest silence is a legitimate government practice if it helps the factfinder discover the truth, yet prearrest silence is but a minimal aid to truth seeking because there are many reasons other than guilt why a defendant might remain silent prior to arrest. In contrast, substantive use of prearrest silence impairs the policies behind the Fifth Amendment. Such use may encourage improper police behavior, may compromise the values of the adversary system, and threatens to convict the innocent. 